\title{
Neoclitocybe infuscata: a new species from Atlantic Forest of Pernambuco State, Brazil
}

\author{
Sá MCA ${ }^{1}$, Silva NA ${ }^{2}$ and Wartchow $\mathrm{F}^{3}$ \\ ${ }^{1}$ Universidade Federal do Rio Grande do Norte, Programa de Pós-Graduação em Sistemática e Evolução, Campus \\ Universitário, Lagoa Nova, CEP 59072-970 Natal, RN, BRAZIL.E-mail: marianasa85@gmail.com \\ ${ }^{2}$ Universidade Federal Rural de Pernambuco, Programa de Pós-Graduação em Etnobiologia e Conservação da \\ Natureza, Rua Dom Manuel de Medeiros s/n, Dois Irmãos, CEP 52171900, Recife, PE, BRAZIL. \\ ${ }^{3}$ Universidade Federal da Paraíba, Departamento de Sistemática e Ecologia, CEP 58051-970, João Pessoa, PB, \\ BRAZIL.
}

Sá MCA, Silva NA, Wartchow F. 2016 - Neoclitocybe infuscata: a new species from Atlantic Forest of Pernambuco State, Brazil. Mycosphere 7(6), 773-777, Doi 10.5943/mycosphere/7/6/7

\begin{abstract}
Neoclitocybe infuscata is a new species from the Brazilian Atlantic forest. It is characterized macroscopically by the grayish brown pileus with a shallow sulcate surface; microscopically by ellipsoid to elongate basidiospores, lacking pleuro- and caulocystidia, abundant cheilocystidia, a sarcodimitic context and pileipellis with rameales-structure and diverticulate terminal elements.
\end{abstract}

Key words - Agaricales - neotropics - taxonomy - Tricholomataceae

\section{Introduction}

Neoclitocybe Singer is a genus characterized by a clitocyboid to omphalioid, rarely pleurotoid habit, a pileipellis with a distinct Rameales-structure, and smooth, inamyloid spores (Singer 1986). According to Largent et al. (1986: 50) the term 'Ramelaes-structure' is also used for species on which the pileipellis hyphae have short vertical branches (in this case, knobs). This genus differs from Clitocybe (Fr.) Staude in the distinct basal mycelium and the 'Ramealesstructure' (i.e. hyphae with diverticulate elements according to Largent et al. 1986) of the pileipellis (Singer 1986).

A list made by Putzke (1994) for Brazilian species reported nine species: N. byssiseda (Bres.) Singer, $N$. irregularis (Rick) Singer, $N$. nauseosa (Rick) Singer, $N$. nivea (Rick) Singer, $N$. subnimbata (Rick) Singer, N. viridilutea (Rick) Singer for Rio Grande do Sul (South Brazil); and $N$. euomphala (Berk.) Singer and $N$. ciliata Singer from Amazonas (North Brazil). In Northeast Brazil, only one species is known, N. sublateralis Singer for Pernambuco (Singer 1965).

This manuscript presents a new species of Neoclitocybe from Northeast Brazil, with a description and drawings.

\section{Materials \& Methods}

The basidiomes were collected at the "Refúgio Ecológico Charles Darwin" $\left(07^{\circ} 48^{\prime} 37\right.$ " $07^{\circ} 49^{\prime} 02^{\prime \prime} \mathrm{S}$ and $\left.34^{\circ} 27^{\prime} 25^{\prime \prime}-34^{\circ} 56^{\prime} 52^{\prime \prime} \mathrm{W}\right)$, is protected private area about 60 ha, located at municipality of Igarassu, in the State of Pernambuco, Northeast Brazil (Costa-Lima 1998).

For macroscopic studies, Singer (1986) was followed. Color codes and numbers are based on Online Auction Color (2004). For better view of the cells Congo red reagent was used, except 
the basidiospores that were measure in Melzer's reagent. Statistics are based on 30 basidiospores measured. Abbreviations include $\mathrm{L}(\mathrm{W})=$ basidiospore length (width) average from a single basidiome, $\mathrm{Q}=$ the length : width ratio range as determined from all measured basidiospores, and $\mathrm{Qm}=$ the $\mathrm{Q}$ value averaged from all basidiospores. MycoBank and Facesoffungi numbers are provided as explained in Crous et al. (2004), Robert et al. (2013) and Jayasiri et al. (2015). The holotype is deposited at JPB (Thiers, continuously updated).

\section{Taxonomy}

Neoclitocybe infuscata Sá \&Wartchow, sp. nov.

Figs. 1-5

MycoBank: MB 815269

Facesoffungi number: 02680

Etymology - From Lat. 'infuscata' (=darkened). Due to dark grayish brown pileus of the new species.

Basidiome small. Pileus 18-20 mm, depressed, dark grayish-brown (OAC 41), surface shallowly sulcate from the center to the margin; margin downturned; context $0.3 \mathrm{~mm}$ thick at centre, gradually thinning towards the margin. Lamellae decurrent with short tooths, subdistant, cream-buff (between OAC753 and OAC 760), $2 \mathrm{~mm}$ broad; lamellulae frequent. Stipe 23-34 $\times 0.2$ $\mathrm{mm}$, central, grayish brown (OAC 41), subcylindrical, slightly tapering above, smooth and hollow.

Basidiospores [30/1/1] (6-)6.5-8.3(-8.5) × 4-4.5(-5) $\mu \mathrm{m}, \mathrm{L}=7.2 \mu \mathrm{m}, \mathrm{W}=4.3 \mu \mathrm{m}, \mathrm{Q}=$ $(1.44-) 1.50-1.88(-1.89), \mathrm{Qm}=1.69 \mu \mathrm{m}$; ellipsoid to elongate, thin-walled, inamyloid, hyaline in $3 \% \mathrm{KOH}$, guttulate. Basidia 25-40 × 6-8.5 $\mu \mathrm{m}$, clavate, with 4 sterigmata $1.5-4.5 \mu \mathrm{m}$ high. Pleurocystidia absent. Lamella edge sterile with crowded and prominent cheilocystidia. Cheilocystidia 22-45 $\times 3-6.5 \mu \mathrm{m}$, fusoid to fusoid- ventricose, thin-walled, hyaline in $\mathrm{KOH} 3 \%$. Lamella trama subregular, sarcodimitic, compose of hyaline hyphae $2.6-5.1 \mu \mathrm{m}$ wide, slightly thick-walled up to $0.5 \mu \mathrm{m}$. Pileus context distinctly sarcodimitic (see Singer 1986). Pileipellis as cutis, with transition to trichoderm in all surface, a Rameales-structure (sensu Largent et al. 1977) of septade diverticulate hyphae, frequently gradually ascending but not hymeniform, terminal elements cylindric $25-55 \times 5-10 \mu \mathrm{m}$ frequently anticlinal, with occasional nodules, hyaline in $\mathrm{KOH} 3 \%$, slightly thick-walled up to $0.5 \mu \mathrm{m}$, and hyphae $4-6 \mu \mathrm{m}$ wide. Stipitipellis as cutis, compose of longitudinally orientated hyphae 3.8-5 $\mu \mathrm{m}$ wide, without caulocystidia. Clamp connections present in all tissues examined.

Distribution - State of Pernambuco.

Habitat - in pairs on soil in Atlantic Forest.

Type - BRAZIL. Pernambuco, Igarassu, Refúgio Ecológico Charles Darwin, 5 June 2012, F. Wartchow \& N.A. Silva FW 44/2012 (JPB 61265, holotype).

\section{Discussion}

The key for the species presented by Singer \& Grinling (1967) separates the species by the size of basidiospores, color of the pileus and lamellae, and $N$. infuscata falls in the group with basidiospores larger than $6 \mu \mathrm{m}$ long and basidiomes without lilac tinges. They listed $N$. subnimbata and $N$. omphalina (Singer) Singer with these key characteristics.

Neoclytocybe subnimbata was revised by Singer (1953) under the name Clitocybe subnimbata Rick and clearly differs in the larger pileus (more than $20 \mathrm{~mm}$ ), white to melleus lamellae and stipe base, smaller basidiospores $4.8-6.9 \times 2.7-4.1 \mu \mathrm{m}$ and rather elongate cheilocystidia that are very irregularly-shaped and some forked or with nodules or protuberances (Singer \& Grinling 1967). Neoclitocybe omphalina (Singer) Singer from northwestern Argentina (as "Marasmiellus omphalina Singer" in Singer \& Digilio 1952) also has a brown, 9-17 mm pileus, but differs in its pileus surface which is radially fibrillose to fibrillose-rimose, glabrous, umbilicate and irregularly sulcate; and white lamellae; the stipe is concolorous to the pileus, 


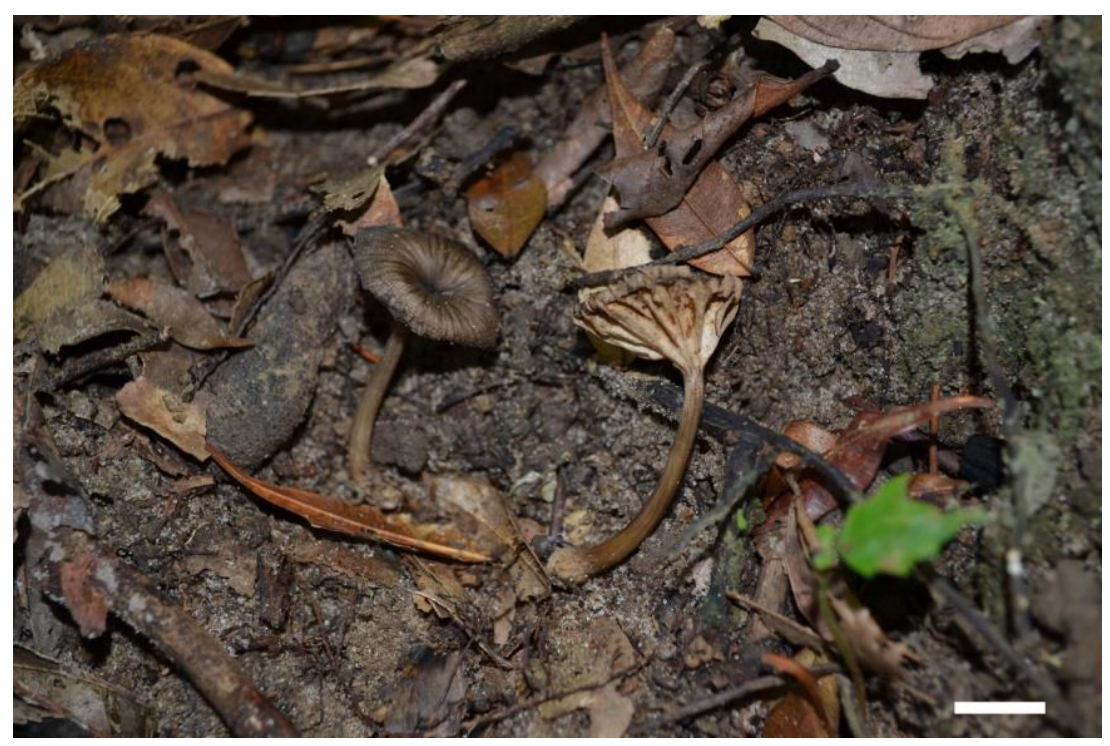

Fig. 1 - Neoclitocybe infuscata (holotype). Basidiomata in situ. Bar $=10 \mathrm{~mm}$.
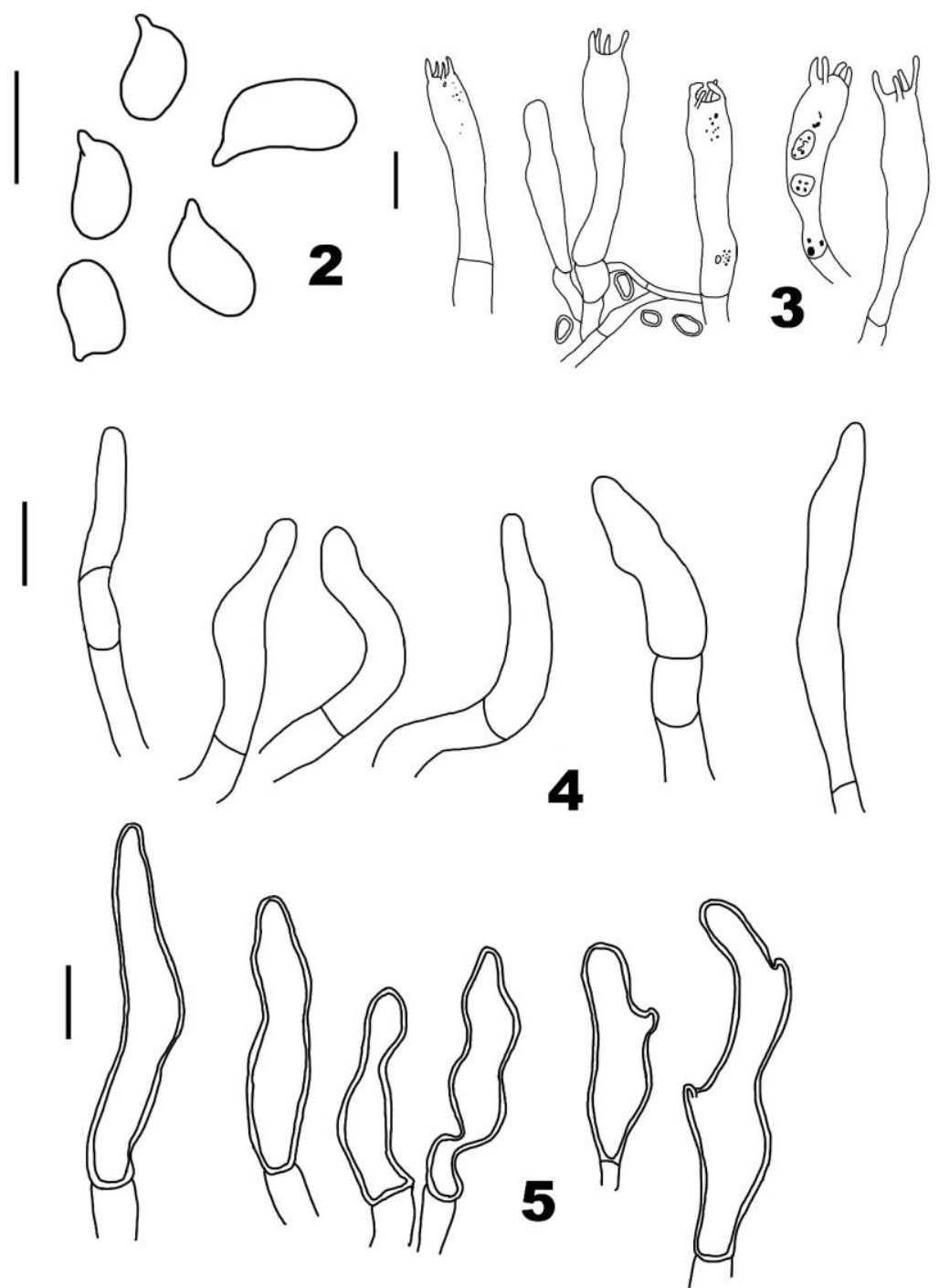

Figs 2-5 - Neoclitocybe infuscata (holotype). 2. Basidiospores. 3. Basidia, basidiole and subhymenium. 4. Cheilocystidia. 5. Terminal elements of the pileipellis. Bars $=10 \mu \mathrm{m}$. 
up to $7-20 \times 1-1.5 \mathrm{~mm}$ and context white; microscopically the basidiospores are slightly larger 7.5-9.5 × 4-4.8 $\mu \mathrm{m}$, ellipsoid with a suprahilar depression; cheilocystidia not abundant, 26-37 $\times$ 5.5-9.7 $\mu \mathrm{m}$, filamentous to ventricose, sometimes with different shapes, and pileipellis a cutis without diverticulate elements (Singer \& Digilio 1952).

Neoclitocybe latispora Singer from Argentina has fuscous pileus measuring 22-46 mm, distinctly larger basidiospores (7-)8.5-8.8(-11.3) $\times(5.5-) 7-7.3(-9.3) \mu \mathrm{m}$, fusoid cheilocystidia with furcated-ramose apex $20-27 \times 4.7-8.5 \mu \mathrm{m}$ and pileipellis as a cutis without any mention of nodules or diverticulate elements (Singer 1973).

Singer (1989) described two additional species. Neoclitocybe sanctarosae Singer from Bolivia differs in the brown to subolivaceous pileus and stipe, white lamellae, narrower basidiospores $6.7-8 \times 3.2-4 \mu \mathrm{m}$, cheilocystidia $25-35 \times 2.5-5 \mu \mathrm{m}$ that are filamentous subventricose to constricted and hyalines, and gelatinous pileipellis as cutis with some erect elements and without diverticulate structures (Singer 1989). Neoclitocybe ciliata, a species from Amazonia, differs in the cinnamon pileus, lamellae and stipe, narrower basidiospores 6.5-9 $\times 2.5-$ $3.7 \mu \mathrm{m}$, presence of ampulaceus or fusoid-ventricose pleurocystidia 15-20 $\times 4-6 \mu \mathrm{m}$ and larger cheilocystidia 45-70 × 3.2-5.5 $\mu \mathrm{m}$ (Singer 1989).

\section{Acknowledgements}

The authors whish thank to Dr. Leonor C. Maia for help and facilities; 'Conselho Nacional de Desenvolvimento Científico e Tecnológico'/CNPq for providing funds for the 'Programa de Pesquisa em Biodiversidade'/PPBio (CNPq/MCT Proc. 60/2009), INCT Herbário Virtual da Flora e dos Fungos (Proc. 573883/2008-4) and SISBIOTA (Proc. 371493/2012-9); and the 'Coordenação de Aperfeiçoamento de Pessoal de Nível Superior'/CAPES for funding the research.

\section{References}

Costa-Lima MLF. 1998 - A reserva da Biosfera da Mata Atlântica em Pernambuco: Situação Atual, Ações e Pespectivas. Série Cadernos da Reserva da Biosfera n 12, São Paulo.

Crous PW, Gams W, Stalpers JA, Robert, Stegehuis G. 2004 - MycoBank: an online initiative to launch mycology into the $21^{\text {st }}$ century. Studies in Mycology 50, 19-22.

Jayasiri SC, Hyde KD, Ariyawansa HA, Bhat J, Buyck B, Cai L, Dai Y-C, Abd-Elsalam KA, Ertz D, Hidayat I, Jeewon R, Gareth Jones EB, Bahkali AH, Karunarathna SC, Liu J-K, Luangsa-ard JJ, Lumbsch HT, Maharachchikumbura SSN, McKenzie EHC, Moncalvo J-M, Ghobad-Nejhad M, Nilsson H, Pang K-L, Pereira OL, Phillips AJL, Raspé O, Rollins AW, Romero AI, Etayo J, Selçuk F, Stephenson SL, Suetrong S, Taylor JE, Tsui CKM, Vizzini A, Abdel-Wahad MA, Wen T-C, Boonmee S, Dai DQ, Daranagama DA, Dissanayake AJ, Ekanayaka AH, Fryar SC, Hongsanan S, Jayawardena RS, Li W-J, Perera RH, Phookamsak R, de Silva NI, Thambugala KM, Tian Q, Wijayawardene NN, Zhao R-L, Zhao Q, Kang JC, Promputtha I. 2015 - The Faces of Fungi database: fungal names linked with morphology, phylogeny and human impacts. Fungal Diversity 74, 3-18.

Largent DL, Johnson D, Watling R. 1986 - How to identify mushrooms to genus III: microscopic features. Eureka, Mad River Press, 148 pp.

Online Auction Color. 2004 - Online Auction Color Chart. Online Auction Color Co., Stanford.

Putzke J. 1994 - Lista dos fungos Agaricales (Hymenomycetes, Basidiomycotina) referidos para Brasil. Caderno de Pesquisa Série Botânica 6, 1-159.

Robert V, Vu D, Amor ABH, van de Wiele N, Brower C, Jabas B Szoke S, Dridi A, Triki M, bem Doud S, Chouchen O, Vaas L, de Cock A, Stalpers JÁ, Stalpers D, Verkley GJM, Groenewald M, Santos FB, Stegehuis G, Li W, Wu L, Zhang R, Ma J, Zhou M, Gorjón SP, Eurwilaichitr L, Ingsriswang S, Hansen K, Schoch C, Robbertse B, Irinyi L, Meyer W, Cardinali G, Hawksworth DL, Taylor JW, Crous PW. 2013 - Mycobank gearing new horizons. IMA Fungus 4, 371-379.

Singer R, Digilio APL. 1952 ('1951') - Pódromo de la flora agaricina Argentina. Lilloa 25, 5-461. 
Singer R, Grinling K. 1967 - Some Agaricales from Congo. Persoonia 4, 355-377.

Singer R. 1953 - Type studies on Basidiomycetes VI. Lilloa 26, 5-159.

Singer R. 1965 - New and interesting Agaricales from Brazil. Atas do Instituto de Micologia da Universidade do Recife 2, 15-59.

Singer R. 1973 - Diagnoses Fungorum Novorum Agaricalium III. Beihefte zur Sydowia 7, 1-106.

Singer R. 1986 - The Agaricales in Modern Taxonomy. (4 ${ }^{\text {th }}$ ed.). Koeltz Scientific Books, Koenigstein.

Singer R. 1989 - New Taxa and New Combinations of Agaricales (Diagnoses Fungorum Novorum Agaricalium IV). Fieldiana, Botany 21, 25-26. 